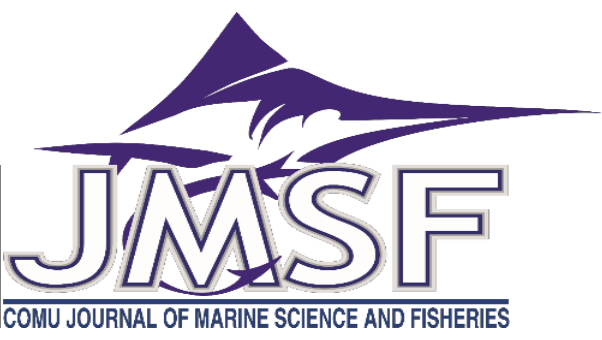

SHORT COMMUNICATION

\title{
A Novel Longline That Can Be Used By a Single Crew in the Aegean Sea: Solo Longline
}

\author{
Cezmi Kançoban, Okan Akyol \\ Ege University Fisheries Faculty 35440 Urla, İzmir, Turkey \\ Correspondent: okan.akyol@ege.edu.tr

How to cite this article: Kançoban, C., \& Akyol, O., (2020). A novel longline that can be used by a single crew in the Aegean Sea: Solo longline. COMU J. Mar. Sci. Fish, 3(1): 45-46. DOI: 10.46384/jmsf.735563

Abstract: This short paper presents an innovation on the use of a bottom longline with only a single crew on a fishing boat in the Aegean Sea. The mainline was $0.80 \mathrm{~mm}$ in diameter and $75 \mathrm{~m}$ in length, with branch lines of $0.45 \mathrm{~mm}$ in diameter and $70 \mathrm{~cm}$ in length. Distance between two adjacent branch lines was $7 \mathrm{~m}$. The total duration of the operation, excluding soak time, was 35 minutes for a total of 40 hooks. Although this small prototype seems to succeed, larger versions may cause operational difficulties. Therefore, we suggest that further handling techniques should be developed in the future for challenging tasks such as baiting and solo using.

Keywords: Bottom, Bait, Hook, Fishing, İzmir

\section{Ege Denizi’nde Tek Kişiyle Kullanılabilen Yeni Bir Paragat: Solo Paragat}

Özet: Bu kısa makale, Ege Denizi'nde tek kişilik (yani solo) bir dip paragatı kullanma yeniliğini sunmaktadır. Ana beden 0,80 mm çapındave $75 \mathrm{~m}$ uzunluğunda ve köstekler $0.45 \mathrm{~mm}$ çapında ve $70 \mathrm{~cm}$ uzunluğundadır. Her iki köstek arasındaki mesafe 7 m'dir. Toplam operasyon süresi 40 kanca için suda bekleme süresi hariç 35 dakikadır. Bu küçük prototip başarılı görünse de daha büyük olanı işlem zorluklarına neden olabilir. Bu nedenle, gelecekte yemleme ve yalnız kullanım zorlukları için daha ileri operasyon tekniklerinin ele alınması gerektiğini öneriyoruz.

Anahtar Kelimeler: Dip, Yem, Kanca, Balıkçılık, İzmir

\section{Introduction}

Longlines are very long lengths of fishing line with short branch lines carrying the hooks at set intervals and are baited with sardine, squids, crabs, shrimps, sea worms, etc. on land or on the way out the fishing grounds (Muus \& Dahlstrom, 1974). Several of these lines may be merged to reach several kilometres. The position of the line and hooks in the water can be adjusted according to the type of the fish that one intends to catch, e.g. near the bottom, or floating in mid-water (Muus \& Dahlstrom, 1974).

The bottom longlines target to catch of sparids, groupers, etc. This fishing type is very popular throughout the Aegean Sea. However, the operation of longline is some complex due to need an additional person for easy operation and bait. Thus, this paper reports an innovation of using a bottom longline by one-man (i.e. solo) in the Aegean Sea.

\section{Material and Methods}

The experimental solo longline was implemented on 19 September 2019 off Özbek, Urla in the Aegean Sea. The longline has 40 hooks and baited with sardine, and deployed to the system on a wooden fishing boat 'Elif'. The boat has $9 \mathrm{hp}$ machine power and $5.5 \mathrm{~m}$ LOA. All operation has been taken by a smart camera on board.

\section{Results and Discussion}

The longline rope is made from mono PA material. The mainline was $0.80 \mathrm{~mm}$ diameter and $75 \mathrm{~m}$ length, and branch line was $0.45 \mathrm{~mm}$ diameter 
and $70 \mathrm{~cm}$ length. Distance between both branch lines was $7 \mathrm{~m}$.

The system was close to the bulwark and fixed on a wooden table. It has two parts: (i) two rotating wheels with a bicycle chain and turned by the hand of fisherman, who sitting on a stool, (ii) basket rotate pedestal. All parts were made from galvanized alloy against to corrosion. This simple system works with the logic of cycling; the first hand wheel which is manually rotated rotates with the basket. The mainline flows through the U type apparatus that attached the gunwale (Figure 1).

The releasing and towing durations were 15 and 20 minutes, respectively. The total duration of the operation, except soak time, was 35 minutes for 40 hooks. The longline was deployed on a sandy bottom with patches of sea meadows at a depth of $10 \mathrm{~m}$ and a short time after; it was started picking up at the end of the buoy. A total of five Painted combers (Serranus scriba) were caught during the experimental operation, even though we were not tending to catch fish

This short paper presents a new longline type by using solo for artisanal fishing. This small prototype was succeeding, although it needs some improvements. And also the bigger one may cause operational difficulties. So, we suggest that the bigger one should be tested in the future to find out the difficulties of baiting and solo using.

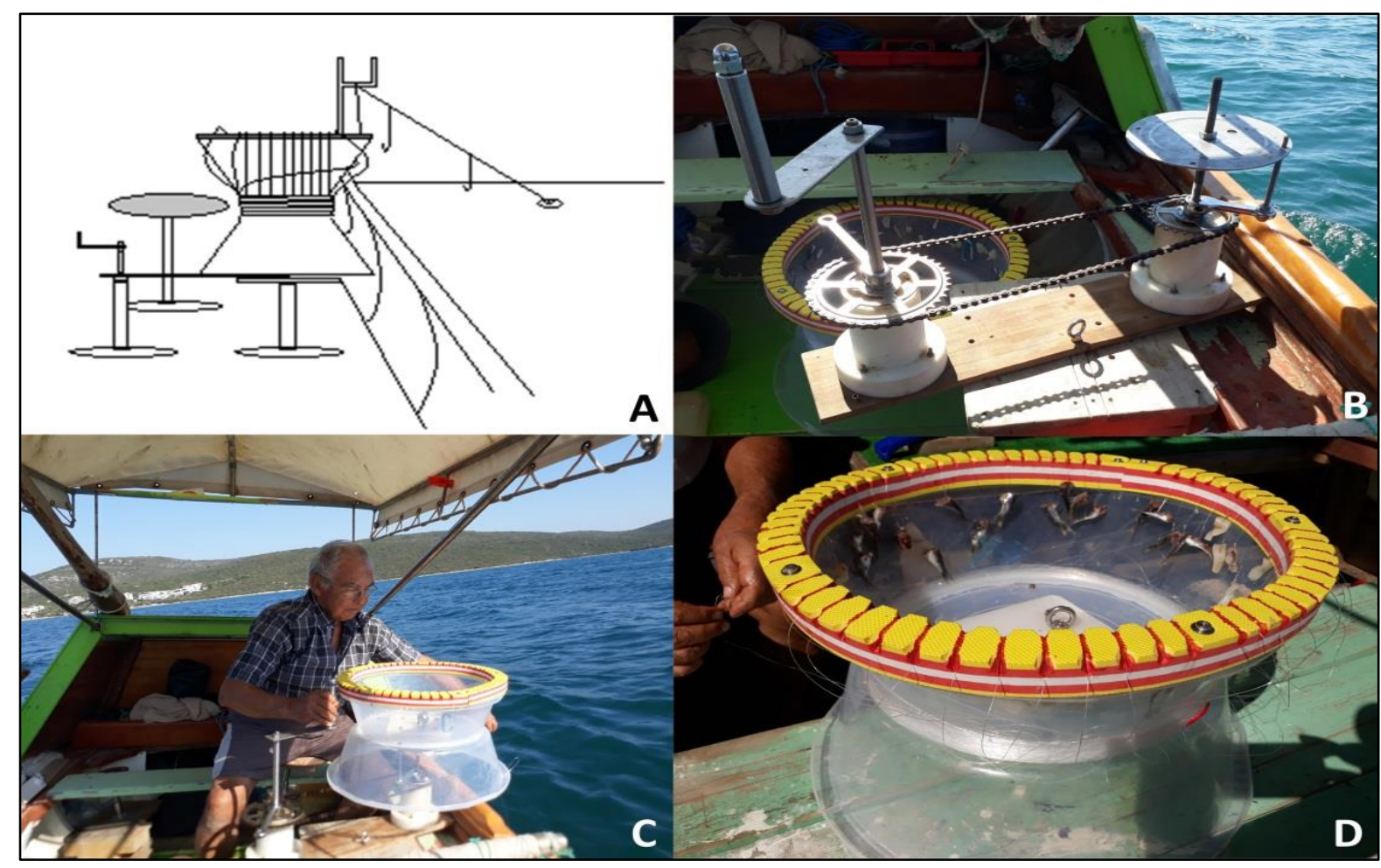

Figure 1. Experimental solo-longline, A: technical drawing (no scale), B: mechanical system, C: operation, D: basket and baits

\section{Reference}

Muus, B.J. \& Dahlstrom, P. (1974). Collins guide to the sea fishes of Britain and North-western Europe. (244 p. Wm. Collins Sons and Co. Ltd.), London and Glascow. 